\title{
Knowing when to quit
}

\author{
Rebecca Coombes head of news and views
}

The BMJ

A research article in The BMJ this week contains a useful message to readers helping patients who are making new year attempts to stop smoking. The risk of developing cardiovascular disease even if patients smoke just one cigarette a day is higher than expected - as much as half the risk of smoking 20 a day - the paper finds (doi:10.1136/bmj.j5855).

The researchers, from University College London, analysed 141 studies to estimate the relative risks of smoking one, five, or 20 cigarettes a day. They found that men who smoked one cigarette a day had $45 \%$ the excess risk of heart disease and $41 \%$ the excess risk of stroke associated with smoking 20 cigarettes a day, relative to non-smokers. That such a low level of smoking carries unexpectedly high risks will surprise many people, says our editorialist Kenneth Johnson (doi:10.1136/bmj.k167): “Only complete cessation is protective and should be emphasised by all prevention measures."

On the subject of quitting, our latest coverage of the collapse of Carillion, a major NHS contractor, asks whether we should be calling time on private sector outsourcing. As the dust settles and the cranes stand idle at two new hospital sites, Nigel Hawkes looks at what happens next for the NHS trusts that depended on the liquidated company (doi:10.1136/bmj.k298). Are there other Carillions waiting in the wings?

Allyson Pollock, professor of public health at Newcastle University, who warned of the dangers of the private finance initiative (PFI) in these pages in 2010 (doi:10.1136/bmj.c7175), says in the New Statesman this week that Carillion's demise is a klaxon warning to the public sector over private financing. The former editor of The BMJ Richard Smith agrees that this is a watershed moment for PFI but doesn't think you can depend entirely on the public purse (doi:10.1136/bmj.k311). Smith edited the journal during the heyday of PFI and recalls the attraction of the policy to ministers: "There are savings in the early years, the costs come later." Around 700 PFI projects later, the poor value for money of such deals has been exposed, most devastatingly by the National Audit Office (doi:10.1136/bmj. k273).

Nevertheless, Smith says that the private sector should have access to the public services market as long as it meets stringent tests. "The public sector should be smart rather than ideological and avoid the illusion of a "free lunch," he says.

When times are tough in the NHS it's vital to recognise all the hard work going on. For a chance for your teamwork and achievement to be recognised, enter The BMJ Awards (thebmjawards.bmj.com/home). Entries are open until Friday 2 February.

\section{Follow Rebecca on Twitter @rebeccacoombes}

Published by the BMJ Publishing Group Limited. For permission to use (where not already granted under a licence) please go to http://group.bmj.com/group/rights-licensing/ permissions 